\title{
CHANGES OF EGG QUALITY PROPERTIES WITH THE AGE OF LAYER HENS IN TRADITIONAL AND CONVENTIONAL PRODUCTION
}

\section{Z. Škrbić ${ }^{1}$ Z. Pavlovski ${ }^{1}$, M. Lukić ${ }^{\text {, D. Vitorović }}{ }^{2}$ V. Petričević ${ }^{1}$, Lj. Stojanović ${ }^{1}$}

${ }^{1}$ Institute for Animal Husbandry, Autoput16, P. Box 23, 11080 Belgrade-Zemun, Republic of Serbia

${ }^{2}$ Faculty of Agriculture, Department of Animal Science, 11080 Belgrade-Zemun, Republic of Serbia Corresponding author: zdskrbic@gmail.com

Original scientific paper

Abstract: The upcoming ban on cage rearing system, ecological aspects of production, perception of better quality and biological safety of products from less intensive systems are reasons in favour of alternative (non-conventional) systems of production of table eggs. Considering only few studies have dealt with quality properties of eggs obtained from autochthonous breeds and changes during production cycle, objective of this study was to define these changes and determine the degree of correlation between the age of layer hens of Banat Naked-Neck breed and quality of eggs in traditional production in relation to conventional, traditional production of light line hybrid of layers in cage system. Results of the study showed poorer quality of eggs from traditional production but certain properties (egg mass, egg shell mass), thanks to strong positive correlation to age of layer hens, were significantly improved, i.e. no decrease with the age of layers was determined, contrary to eggs from conventional production.

Key words: egg quality, age of hens, traditional, conventional, production

\section{Introduction}

Traditional production of table eggs, as form of extensive production, is based on native hen populations, without significant market orientation. Intensive production, in battery cages, in general has enabled progress in production of table eggs in regard to production level, economical efficiency, hygiene-health safety, etc. However, alternative (non-conventional) production systems, due to legislative regulations which relates to provision of welfare conditions to layer hens, and upcoming ban on cage rearing system, ecological aspects, perception of better quality and biological safety of products from less intensive systems, are taking an increasingly important role in total production of table eggs. 
The dominance of intensive production of table eggs directed all research towards one aim to determine the effects of numerous factors on productivity of light line hybrids of layer hens and quality of eggs from cage system. It is known that the egg quality properties are genetically determined, but also under significant influence of housing system (Pavlovski et al., 2002; Rossi, 2007), nutrition, especially mineral (Lukić et al., 2009), oviposition (Škrbić et al., 1998), producer and production management (Škrbić et al., 2006), storage conditions and transport of eggs (Pavlovski et al., 1996). In case of same layer genotype, nutrition, housing, changes in certain quality properties of fresh eggs depend exclusively on biological cycle, i.e. age of layer hens (Pavlovski et al., 1997).

Considering the moderate data in literature which relate to changes in the quality of fresh eggs from autochthonous breeds during production cycle, objective of this study was to define these changes and determine the degree of correlation between the age of layer hens of Banat Naked-Neck breed and quality of eggs in traditional production in relation to conventional production of light line hybrid of hens in cage system.

\section{Materials and Methods}

Quality properties were analyzed on 240 eggs ( 8 periods/layer hen ages $\mathrm{x}$ 30 eggs) from traditional (T), and conventional (C) production.

Traditional production is defined as extensive production with autochthonous hen of Banat Naked-Neck breed. Layers were housed in a facility with floor system with feeders, waterers and nests, as well as free range - natural pasture, surrounded by fence, according to technology of Pavlovski et al. (2010).

Conventional production included cage rearing system, with 4 hens of Lohmann Brown hybrid in one cage. Applied production technology was in concordance with norms of standard technology applied in intensive production of table eggs. Feeding program was designed according to requirements of layer hens in certain production periods (Table 1). Nutrition of Naked-neck hens was based on same mixtures with additional food that hens consumed on pasture.

Table 1. Nutritive value of feed mixtures for layer hens

\begin{tabular}{|l|c|c|c|}
\hline \multirow{2}{*}{ Parameters } & \multicolumn{3}{|c|}{ Age, week } \\
\cline { 2 - 4 } & $24-32$ & $33-44$ & $45-52$ \\
\hline ME, MJ & 11.68 & 11.51 & 11.53 \\
\hline Crude protein, \% & 17.4 & 16.6 & 16.2 \\
\hline Ca, \% & 3.9 & 4.0 & 4.0 \\
\hline P, \% & 0.71 & 0.66 & 0.60 \\
\hline
\end{tabular}

Trial period lasted from the 24th to 52nd week of age of layer hens, in the period from May to November. In four week intervals properties of external and 
internal egg quality (Pavlovski et al., 1997) and egg shell quality (Pavlovski and Vitorović, 1996) were analyzed.

Statistical analysis of data was done with software program SPSS version 16.0 and it was based on determination of parameters of descriptive statistics and correlation analysis of the age of layer hens and egg quality properties.

\section{Results and Discussion}

Average laying rate of layers during trial period was $88.80 \%$ in conventional, i.e. $59.19 \%$ in traditional production. Laying intensity in control periods is presented on Graph 1.

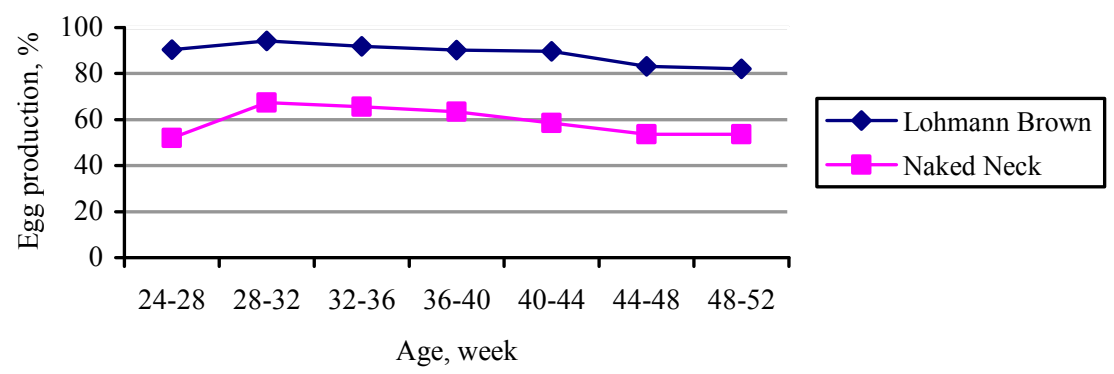

Graph 1. Laying rate intensity (\%) of Lohmann Brown and Banat Naked-Neck hens during trial period

Egg production line shows only moderate differences during laying period, but thanks to genetic progress, higher production level of eggs of Lohmann Brown hens compared to Banat Naked-Neck hen. Egg production of Banat Naked-Neck hen was at the level of pure breeds and conserved lines in trial realized by Krawczyk (2009) who reported of changes in certain egg quality parameters in accordance with the production level.

Changes in egg quality traits and correlation degree to age of hens in conventional and traditional production, are presented in Tables 2 to 4 .

The egg mass increased with the age of hens in both investigated groups. Contrary to conventional production, where main objective is to achieve slightly curved line for the egg mass, with small number of small eggs at the beginning and not too large eggs at the end of production cycle (Förster and Flock, 1997), mass of eggs from traditional production showed continuous increase with the age of hens. Hence, strong positive correlation $(\mathrm{r}=0.77)$ between egg mass and age of hens in group $\mathrm{T}$ was determined, whereas in group $\mathrm{C}$ the correlation coefficient of 0.29 was established. 
Table 2. Correlation coefficients (r) between properties of external egg quality and age of hens in conventional and traditional production

\begin{tabular}{|c|c|c|c|c|c|}
\hline \multirow[b]{2}{*}{ Treatment } & \multirow{2}{*}{$\begin{array}{l}\text { Age of } \\
\text { hens, } \\
\text { week }\end{array}$} & \multicolumn{4}{|c|}{ Properties, Mean \pm SD } \\
\hline & & Egg weight, g & $\begin{array}{c}\text { Eggshell } \\
\text { colour, point }\end{array}$ & $\begin{array}{c}\text { Eggshell } \\
\text { cleanliness, point }\end{array}$ & $\begin{array}{l}\text { Egg shape } \\
\text { index }\end{array}$ \\
\hline \multirow{4}{*}{$\mathrm{C}$} & 24 & $58.43 \pm 4.09$ & $3.80 \pm 0.66$ & $4.03 \pm 1.30$ & $78.07 \pm 2.12$ \\
\hline & 32 & $65.57 \pm 3.10$ & $3.53 \pm 0.78$ & $4.70 \pm 0.79$ & $78.17 \pm 2.26$ \\
\hline & 40 & $64.57 \pm 4.61$ & $3.23 \pm 0.57$ & $4.80 \pm 0.76$ & $78.63 \pm 1.83$ \\
\hline & 52 & $63.69 \pm 5.17$ & $3.43 \pm 0.63$ & $3.73 \pm 0.87$ & $77.43 \pm 2.06$ \\
\hline \multicolumn{2}{|c|}{ Coeff. corr. (r) } & $0.29^{* *}$ & $-0.15^{*}$ & $-0.17^{* *}$ & $-0.15^{*}$ \\
\hline \multicolumn{2}{|c|}{ Significance ( $\mathrm{p}$ value) } & $<0.01$ & 0.02 & 0.01 & 0.02 \\
\hline \multirow{4}{*}{$\mathrm{T}$} & 24 & $43.42 \pm 3.51$ & $2.43 \pm 0.9$ & $3.63 \pm 1.63$ & $73.17 \pm 2.59$ \\
\hline & 32 & $51.03 \pm 4.39$ & $2.40 \pm 0.56$ & $4.13 \pm 1.57$ & $75.70 \pm 2.48$ \\
\hline & 40 & $56.09 \pm 4.48$ & $2.10 \pm 0.48$ & $4.37 \pm 1.10$ & $75.57 \pm 3.32$ \\
\hline & 52 & $60.13 \pm 4.21$ & $2.03 \pm 0.41$ & $4.63 \pm 1.03$ & $74.00 \pm 3.66$ \\
\hline \multicolumn{2}{|c|}{ Coeff. corr. (r) } & $0.77^{* *}$ & $-0.31^{* *}$ & $0.12^{\mathrm{ns}}$ & $0.11^{\mathrm{ns}}$ \\
\hline \multicolumn{2}{|c|}{ Significance ( $\mathrm{p}$ value) } & $<0.01$ & $<0.01$ & 0.08 & 0.09 \\
\hline
\end{tabular}

Egg shell colour, which is genetically determined trait, is important from the aspect of consumer attitude showing preference for certain egg colour. Breeding companies included the colour and even intensity of the egg shell colour into their breeding goals. Because of this, eggs from light line hybrid hens and conventionally produced had darker egg shell colour which was in minor correlation with the age of hens. Intensity of egg shell colour determined in case of Banat Naked-Neck hens was lower and in moderate negative correlation with the age of hens. Namely, poorer pigmentation of egg shell is associated with egg size, which increases with the age of hens and isn't proportional to the amount of pigment deposited in the shell (Odabasi et al., 2007). Cleanliness of egg shell cannot be put in correlation with the age of hens since this trait is mainly influenced by the housing system, season and execution of certain technological procedures. Eggs from traditional production had the highest degree of cleanliness in the last control period - spring season, whereas in conventional production, situation was to the contrary, because of intensive use of equipment and cages, there was no opportunity for their detailed cleaning. Shape of eggs from conventional production was more "round" and in minor negative correlation with the age of hens. Banat Naked-Neck hen produced more "pointy" eggs of lower shape index and without any correlation to the age of hens. 
Table 3. Correlation coefficients ( $r$ ) between properties of internal egg quality and age of hens in conventional and traditional production

\begin{tabular}{|c|c|c|c|c|c|}
\hline \multirow{2}{*}{ Treatment } & \multirow{2}{*}{$\begin{array}{l}\text { Age of } \\
\text { hens, } \\
\text { week }\end{array}$} & \multicolumn{4}{|c|}{ Properties, Mean \pm SD } \\
\hline & & $\begin{array}{l}\text { Yolk colour, } \\
\text { Roche }\end{array}$ & $\begin{array}{c}\text { Albumen high, } \\
0.1 \mathrm{~mm}\end{array}$ & Haugh Units & $\begin{array}{c}\text { Alb./yolk } \\
\text { ratio }\end{array}$ \\
\hline \multirow{4}{*}{$\mathrm{C}$} & 24 & $12.47 \pm 0.68$ & $101.30 \pm 10.88$ & $100.00 \pm 4.75$ & $2.40 \pm 0.28$ \\
\hline & 32 & $11.57 \pm 0.77$ & $86.77 \pm 10.61$ & $91.23 \pm 5.42$ & $2.28 \pm 0.27$ \\
\hline & 40 & $11.77 \pm 0.50$ & $84.43 \pm 14.22$ & $89.73 \pm 7.91$ & $2.23 \pm 0.28$ \\
\hline & 52 & $11.93 \pm 0.78$ & $74.57 \pm 10.62$ & $84.63 \pm 6.42$ & $2.30 \pm 0.22$ \\
\hline \multicolumn{2}{|c|}{ Coeff. corr. (r) } & $0.49^{* *}$ & $-0.57^{* *}$ & $-0.58^{* *}$ & $-0.2^{* *}$ \\
\hline \multicolumn{2}{|c|}{ Significance ( $\mathrm{p}$ value) } & $<0.01$ & $<0.01$ & $<0.01$ & $<0.01$ \\
\hline \multirow{4}{*}{$\mathrm{T}$} & 24 & $12.93 \pm 1.14$ & $69.57 \pm 11.43$ & $87.80 \pm 6.74$ & $1.73 \pm 0.19$ \\
\hline & 32 & $12.37 \pm 0.76$ & $65.47 \pm 17.46$ & $82.07 \pm 10.96$ & $1.69 \pm 0.15$ \\
\hline & 40 & $13.20 \pm 0.55$ & $69.97 \pm 13.39$ & $83.80 \pm 7.98$ & $1.67 \pm 0.15$ \\
\hline & 52 & $12.90 \pm 0.88$ & $68.00 \pm 13.54$ & $79.97 \pm 9.20$ & $1.65 \pm 0.32$ \\
\hline \multicolumn{2}{|c|}{ Coeff. corr. (r) } & $0.19^{* *}$ & $-0.04^{\mathrm{ns}}$ & $-0.21^{* *}$ & $-0.17^{* *}$ \\
\hline \multicolumn{2}{|c|}{ Significance (p value) } & $<0.01$ & 0.55 & $<0.01$ & $<0.01$ \\
\hline
\end{tabular}

Intensity of yolk colour was in concordance with research results of Van den Brand et al. (2004) indicating more intensive colour of yolk from older hens in systems with free range, because of greater consumption of green mass. Contrary to this, Rossi (2007) reports of intensive yolk colour in eggs from cage system, as the effect of producer and rearing system, i.e. farm. This study showed moderate positive correlation between yolk colour and age of hens in conventional production which can be associated with pigment reserves and decrease in laying rate which is in concordance with results of Krawczyk (2009).

Eggs from younger layers have good parameters of egg freshness, i.e. ratio between albumen height and Haugh units. In addition to age of hens (Pavlovski et al., 2000; Škrbić et al., 2004), albumen height is under significant influence of genotype (Silversides and Scott, 2001) and housing system (Đukić Stojčić et al., 2009). Accordingly, the difference between conventional and traditional production in correlation between these parameters with the age of hens is pronounced $(\mathrm{r}=$ 0.57 to $-0.04, \mathrm{r}=-0.58$ to -0.21 , respectively). Eggs of Banat naked-neck hen had lower albumen height in all control measuring periods, and it was not in correlation to age of hens, whereas in case of Haugh units, week correlation was determined as result of known effect of egg mass. Composition of eggs, i.e. shares of three structural parts (albumen, yolk, eggshell) is relatively insensitive to changes in numerous environment factors. Biologically, albumen/yolk ratio changes with the age of hens, in away that share of yolk increases. Silversides and Scott (2001) state significantly higher share of yolk and lower shares of eggshell and albumen in egg mass under the influence of age of hens. Results of our study indicated lower albumen/yolk ratio in eggs of Naked Neck hens, as well as that correlation coefficients between albumen/yolk ratio, i.e. share of eggshell and age of hens were low in both investigated groups. 
Table 4. Correlation coefficients (r) between eggshell quality and age of hens in conventional and traditional production

\begin{tabular}{|c|c|c|c|c|c|c|}
\hline \multirow[b]{2}{*}{ Treatment } & \multirow[b]{2}{*}{$\begin{array}{c}\text { Age of } \\
\text { hens, week }\end{array}$} & \multicolumn{5}{|c|}{ Properties, Mean \pm SD } \\
\hline & & $\begin{array}{l}\text { Eggshell } \\
\text { weight, g }\end{array}$ & $\begin{array}{c}\text { Eggshell, } \\
\%\end{array}$ & $\begin{array}{c}\text { Eggshell } \\
\text { deformation, } \\
0.001 \mathrm{~mm}\end{array}$ & $\begin{array}{c}\text { Eggshell } \\
\text { thickness, } \\
0.01 \mathrm{~mm}\end{array}$ & $\begin{array}{l}\text { Eggshell } \\
\text { breaking } \\
\text { force, } \mathrm{kg}\end{array}$ \\
\hline \multirow{4}{*}{$\mathrm{C}$} & 24 & $8.25 \pm 1.07$ & $14.12 \pm 1.67$ & $21.50 \pm 3.21$ & $34.50 \pm 2.35$ & $2.93 \pm 0.31$ \\
\hline & 32 & $9.27 \pm 1.14$ & $14.17 \pm 1.92$ & $20.40 \pm 3.44$ & $35.37 \pm 1.79$ & $2.84 \pm 0.51$ \\
\hline & 40 & $8.83 \pm 1.00$ & $13.70 \pm 1.50$ & $20.83 \pm 2.91$ & $35.33 \pm 2.23$ & $2.66 \pm 0.33$ \\
\hline & 52 & $8.96 \pm 1.04$ & $14.08 \pm 1.29$ & $21.17 \pm 2.89$ & $35.93 \pm 3.75$ & $2.66 \pm 0.51$ \\
\hline \multicolumn{2}{|c|}{ Coeff. corr. (r) } & $0.13^{*}$ & $-0.04^{\mathrm{ns}}$ & $0.14^{\mathrm{ns}}$ & $0.26^{* *}$ & $-0.2^{* *}$ \\
\hline \multicolumn{2}{|c|}{ Significance (p value) } & 0.04 & 0.58 & 0.84 & $<0.01$ & $<0.01$ \\
\hline \multirow{4}{*}{$\mathrm{T}$} & 24 & $5.77 \pm 0.48$ & $13.32 \pm 0.86$ & $23.20 \pm 3.46$ & $33.80 \pm 2.26$ & $2.33 \pm 0.3$ \\
\hline & 32 & $6.55 \pm 0.98$ & $12.84 \pm 1.56$ & $25.50 \pm 4.63$ & $29.20 \pm 2.51$ & $2.36 \pm 0.37$ \\
\hline & 40 & $7.35 \pm 1.11$ & $13.07 \pm 1.33$ & $24.10 \pm 3.51$ & $32.23 \pm 3.13$ & $2.44 \pm 0.46$ \\
\hline & 52 & $7.59 \pm 1.13$ & $12.60 \pm 1.30$ & $27.23 \pm 5.22$ & $31.60 \pm 2.31$ & $2.21 \pm 0.33$ \\
\hline \multicolumn{2}{|c|}{ Coeff. corr. (r) } & $0.53^{* *}$ & $-0.14^{*}$ & $0.21^{* *}$ & $-0.05^{\mathrm{ns}}$ & $0.05^{\text {ns }}$ \\
\hline \multicolumn{2}{|c|}{ Significance (p value) } & $<0.01$ & 0.03 & $<0.01$ & 0.4 & 0.43 \\
\hline
\end{tabular}

Indicators of the eggshell quality in conventional production were better in all control periods compared to traditional production. Van den Brand et al. (2004) established difference in eggshell quality between cage system and system with free range, where they determined that the eggshell quality decreased with the age of hens in cage system, as well as in the free range system. Considering that mentioned studies were realized on hybrid layers in different rearing systems, results of our research can be explained by differences in genetic basis of layer hens. Eggshell mass, analogue to egg mass, was in strong correlation with the age of Naked Neck hens $(\mathrm{r}=0.53)$ compared to hybrid layers $(\mathrm{r}=0.13)$. Significant correlation coefficient was determined between the age of hens and eggshell thickness $(\mathrm{r}=0.26)$, i.e. breaking force $(\mathrm{r}=-0.2)$ in Lohmann Brown, and between age of hens and eggshell deformation in Naked Neck hens $(\mathrm{r}=0.21)$. Interestingly, even though eggshell thickness increased with the age of hens in group C, breaking force decreased which indicates presence of the problem of eggshell structure (Solomon, 1994).

\section{Conclusion}

Presented results confirmed the presence of differences in the egg quality between autochthonous breeds in traditional production and eggs of hybrid layer hens from conventional production, as well as differences in changes of certain egg quality properties with the age of hens.

Eggs from younger layers obtained in traditional production were of poorer quality, but certain properties (egg mass, eggshell mass), due to strong positive 
correlation with the age of hens were considerably improved and contrary to this, internal egg quality held at the same level, i.e. it didn't decrease with the age of hens, contrary to eggs from conventional production. In general, determined correlation coefficients between major egg quality properties and age of hens are in favour of longer exploitation period of Naked Neck hens in conditions of traditional production.

\title{
Acknowledgment
}

This research is part of the Project TR-31033 financial supported by Ministry of Education and Science of the Republic Serbia.

\section{Promene osobina kvaliteta jaja sa uzrastom nosilja u tradicionalnoj i konvencionalnoj proizvodnji}

\author{
Z. Škrbić, Z. Pavlovski, M. Lukić, D. Vitorović, V. Petričević, Lj. Stojanović
}

\section{Rezime}

Predstojeća zabrana kaveznog sistema gajenja, ekološki aspekti proizvodnje, percepcija boljeg kvaliteta i biološke bezbednosti proizvoda iz manje intenzivnih sistema su razlozi koji idu u prilog alternativnim (nekonvencionalnim) sistemima proizvodnje jaja za konzum. Obzirom na mali broj istraživanja koja su se bavila osobinama kvaliteta jaja autohtonih rasa i promenama tokom proizvodnog ciklusa, cilj ovog rada je bio da se definišu te promene i odredi stepen korelacije između starosti kokoši banatskog gološijana i kvaliteta jaja u tradicionalnoj proizvodnji u odnosu na klasičnu, konvencionalnu proizvodnju lakog linijskog hibrida kokoši u kaveznom sistemu. Rezultati rada su ukazali na lošiji kvalitet jaja iz tradicionalne proizvodnje ali su pojedine osobine (masa jajeta, masa ljuske) zahvaljujući jakoj pozitivnoj korelaciji sa uzrastom nosilja značajno poboljšane i suprotno, unutrašnji kvalitet jaja je održan na istom nivou, odnosno nije se smanjivao sa uzrastom nosilja, suprotno jajima iz konvencionalne proizvodnje.

\section{References}

ĐUKIĆ-STOJČIĆ M., PERIĆ L., BJEDOV S., MILOŠEVIĆ N. (2009): The quality of table eggs produced in different housing systems. Biotechnology in Animal Husbandry, 25, 5-6, Book 2, 1103-1108. 
FURSTER A., FLOCK D.K. (1997): Egg quality criteria for table eggs and egg products. Proceedings of the VII European Symposium on the Quality of Eggs and Egg Products, Poznan, 28-38.

KRAWCZYK J. (2009): Effect of layer age and egg production level on changes in quality properties of eggs from hens of conservation breeds and commercial hybrids. Annals of Animal Science, 9, 2, 185-193.

LUKIĆ M., PAVLOVSKI Z., ŠKRBIĆ Z. (2009): Mineral nutrition of modern poultry genotypes. Biotechnology in Animal Husbandry, 25, 5-6, Book 1, 399411.

ODABASI A.Z., MILES R.D., BALABAN M.O., PORTIER K.M. (2007): Changes in brown eggshell color as the hen ages. Poultry Science, 86, 356-363.

PAVLOVSKI Z., ŠKRBIĆ Z., LUKIĆ M., KRNJAJA V., BIJELIĆ Z., TRENKOVSKI S. (2010): Tehnologija proizvodnje jaja sa slobodnog ispusta posebnog i garantovanog kvaliteta. Biotechnology in Animal Husbandry, 26, spec issue, 55-67.

PAVLOVSKI Z., CMILJANIĆ R., HOPIĆ S. (1996): Inicijalni kvalitet jaja i njegove promene u uslovima skladištenja i tržišta. Tehnologija mesa, 3-4, 87-91.

PAVLOVSKI Z, HOPIĆ S., MAŠIĆ B., LUKIĆ M. (2000): Uticaj ovipozicije i uzrasta nosilja na važnije osobine kvaliteta jaja. Biotehnologija u stočarstvu, 5-6, 55-62. PAVLOVSKI Z., LUKIĆ M., ŠKRBIĆ Z. (2002): Uticaj sistema držanja kokoši nosilja na kvalitet i neškodljivost konzumnih jaja. Biotehnologija u stočarstvu, 5-6, 121-127.

PAVLOVSKI Z., CMILJANIĆ R., HOPIĆ S., VRAČAR S. (1997): Promene u kvalitetu jaja u zavisnosti od starosti kokoši i sprata baterije. Biotehnologija u stočarstvu, 13, 1-2, 43-50.

PAVLOVSKI Z., VITOROVIĆ D. (1996): Direktan metod za odredjivanje čvrstoće ljuske jaja. Nauka u živinarstvu, 3-4, 171-175.

ROSSI M. (2007): Influence of the laying hen housing systems on table egg characteristics. Proceedings XVIII European Symposium on the Quality of Poultry Meat and XII European Symposium on the Quality og Eggs and Egg Products, Prague, 49-51.

SILVERSIDES F.G., SCOTT T.A. (2001): Effect of storage and layer age on quality of eggs from two lines of hens. Poultry Science, 80, 1240-1245.

SOLOMON S.E. (1994): Egg shells: patterns of mineralisation. Poultry International, 50-53.

ŠKRBIĆ Z., PAVLOVSKI Z., MITROVIĆ S., LUKIĆ M., TOMAŠEVIĆ D. (2006): Varijabilnost pojedinih osobina kvaliteta jaja za konzum u zavisnosti od proizvođača i godine ispitivanja. Biotehnologija u stočarstvu, 5-6, 21-33.

ŠKRBIC Z., MITROVIĆ S., PAVLOVSKI Z., LUKIĆ M. (2004): Effects of producer and season on internal quality trait of table eggs from Isabrown layers. XXII World's Poultry Congress, Istanbul-Turkey, 8-13 June, Book of Abstracts, 386 (full text in CD). 
ŠKRBIĆ Z., PAVLOVSKI Z., HOPIĆ S., VRAČAR S., LUKIĆ M. (1998): Uticaj vremena ovipozicije i sprata baterije na kvalitet ljuske jaja. Nauka u živinarstvu, 12, 207-210.

VAN DEN BRAND H., PARMENTIER H.K., KEMP B. (2004): Effects of housing system (outdoor vs cages) and age of laying hens on egg characteristics. British Poultry Science, 45, 6, 745-752.

Received 30 June 2011; accepted for publication 15 August 2011 